\title{
FACTORS AFFECTING THE LINKAGE OF THE FISHERIES SUPPLY CHAIN IN BA RIA VUNG TAU PROVINCE, VIETNAM
}

\author{
Ai Tran Huu \\ My Pham Thi Chieu \\ Thanh Duong Kim
}

Van Hien University, Ho Chi Minh City, Vietnam

The purpose of this study is to test the relationship between the premise factors and business results of organizations involved in the fishery supply chain in Ba Ria - Vung Tau province. The research results show that the risk factors in the supply chain affect supply chain linkages, including risk from the supply, market risks, and information risks. More specifically, risks from the supply are negatively related to supplier links. This is consistent with the views of (Frohlich \& Westbrook, 2001; Zhao et al., 2013) but this also contrasts with the theory of the relationship between environment and organization. If some supply is problematic, people would be ready to look for new suppliers. This may also be the focus of trust and commitment in business relations between organizations in Vietnam. The results of this study indicate that the risk from supply does not usually have any impact on customers. This is in contrast with the research results of (Frohlich \& Westbrook, 2001; Zhao et al., 2013). Finally, the risks from the environment surprisingly show no impact on supply chain linkages. This result is completely contrary to the research results obtained by (Khan \& Burnes, 2007).

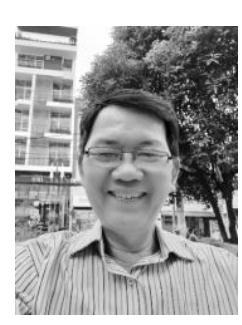

\author{
Ai Tran Huu \\ $\mathrm{PhD}$, Lecturer at the Faculty of Economics, Van Hien University, Ho Chi Minh City, \\ Vietnam. \\ Research interests: markets of agricultural products; SMEs functioning and government \\ support; organic food markets; ecological economics; environmental issues of \\ economic development and corporate social responsibility. \\ Published more than 60 papers in international journals. \\ E-mail: aith@vhu.edu.vn
}

\section{My Pham Thi Chieu}

MBA, Lecturer at the Faculty of Economics, Van Hien University, Ho Chi Minh City, Vietnam

Research interests: markets of agricultural products; organic food markets

E-mail: myptc@vhu.edu.vn

\section{Thanh Duong Kim}

MBA, Lecturer at the Faculty of Economics, Van Hien University, Ho Chi Minh City, Vietnam

Research interests: SMEs' support, markets of agricultural products

E-mail: thanhdk@vhu.edu.vn 


\section{FACTORS AFFECTING THE LINKAGE}

Keywords: fisheries; supply chain; risk from supply; market risks; information risks

\section{Introduction}

As the economy grows, specialization is nearly always increasing, organizations tend to strengthen cooperation with other members of the supply chain to use resources of partners under lower than market costs. Therefore, organizations increasingly want to come together to effectively manage their supply as well as distribution channels with the aim to optimize costs, while increasing customer satisfaction, contributing to higher competitiveness and profitability of participating organizations (Lee \& Whang, 2000; Anderson \& Weitz, 1992).

Therefore, many researchers agree that competition is taking place between the supply chain and also within the supply chain. Many scholars and managers have defined supply chain management as the management of the links between basic business processes from the end consumer to the first supplier, as these links are providing products, services and also information to optimize the value added for supply chain customers and other interested organizations (Lambert \& Cooper, 2000). Supply chain management is the management of the links between all activities related to the flow and conversion of goods and information from being raw materials to the stage of reaching end consumers, thus achieving a durable competitive advantage for the firm. Supply chain linkages can be multiple levels, they can be also loose or tight. Many researchers have tried to find and determine the prerequisites for the organizations involved in supply chain linkages. Many scholars argue that the supply chain linkage is always under the global competitive pressure or the risk of environmental fluctuations including changes in supply, demand, technologies' development (Chen \& Paulraj, 2004; Mentzer et al., 2000) and new market opportunities (Frohlich \& Westbrook, 2001).

The impact of risk on the level of alignment is consistent with the theory of the relationship between environment and organization (Aldrich \& Pleffer, 1976). Experiencing environmental changes, organizations should also change and develop to survive. Organizations tend to strengthen relationships to limit the impact of supply, demand, technology and environment instability (Mentzer et al, 2001; Chen \& Paulraj, 2004).

However, views on the nature of this relationship are often contradictory. Some authors believe that this is a positive relationship, meaning that when the environment is more unstable and risky, organizations tend to strengthen links between them. Meanwhile, some other studies determine that this relationship is counterclockwise: the higher is the risk, the less are organizations associated with each other (Zhao et al., 2013). Therefore, continuing to explain this relationship is necessary. One of the possible explanations concerns the effect of the moderating variable in this relationship.

The aquaculture industry of the Bà Rịa Vung Tau province is greatly affected by many factors. Like with agricultural products, risk is always an important issue in production and business activities within the fisheries sector as it is significantly affecting the linkages between businesses in this industry, both cross-linking and vertical integration. However, until now, seafood enterprises, including those in Ba Ria Vung Tau, are still confused in identifying strategies and how to coordinate them to be able to manage risks wisely. This industry is also the industry with many stages in the supply chain. 
The concept of supply chains has been developed for many different areas of human activity (Chen \& Paulraj, 2004) but primarily for materials and logistics management, network governance and market connectivity and so on. There are many concepts essentially similar to the supply chain concept, for example, "demand chain", "value chain" and "support chain".

However, the most common among them is still supply chain concept which was developed by Lambert, D. \& Cooper, M. (2000) and Christopher, M. \& Lee, H. L. (2004). Similarly, Lambert, D. \& Cooper, M. (2000) defined supply chain as a partnership between businesses to bring products and services to markets. Finally, supply chain can also be understood as a network of organizations, including their upstream linkages and downstream linkages, through processes and activities, with the aim to create value for products and services offered at the market.

\section{Theoretical Background of the Study}

Many activities need to be managed within the supply chain effectively. This transforms the management philosophy into specific activities, including: cooperative perception, sharing risks and benefits (Cooper et al., 1997), cooperation, working towards target customers, long-term relations. Our study will only focus on the activity most commonly referred to as supply chain management, in its both academic and practical meanings, seen here as an integration of businesses.

In recent years, many large companies have succeeded in managing supply networks. The most impressive examples in this regard include: Hewlett-Packard, Compaq, Digital Equipment Corporation, Xerox and Benetton Group. The common peculiarity of all these companies is that they are not aiming to increase profits at each stage, instead, they are aiming to increase competitiveness for the entire chain or supply network. In such a way, all companies in a supply chain improve their competitiveness and gain many benefits through more efficient use of resources (Cooper et al., 1997). This success demonstrated in real business practice has changed the definition of supply chain management, gradually shifting its original focus on linking logistics operations to a broader concept of linking all basic business processes (Cooper et al., 1997).

Linking research logistics activities is quite popular in supply chain management. This affiliate activity involves both inside and outside businesses. Logistics linkages within enterprises imply cooperation of logistics-related activities such as inventory management, freight transport, warehousing management, order and purchase management. External logistic linkages are divided into two directions - downstream links and upstream links.

Linking information means sharing information between businesses, at both strategic and operational levels. Sharing at the strategic level assumes that the information shared with partners will create more value than that obtained by just one member.

Conversely, reverse links or reverse logistics usually has the task of recalling products and moving to the partners outside the chain, responsible for receiving or repairing products from customers. Supply chain management is linking business processes from consumers to distributors, producers, and suppliers of materials with the aim to create value from products or services.

Linking supply chains includes both internal and external links. Internal linkage implies cooperation between departments and internal departments. Linking with suppliers 


\section{FACTORS AFFECTING THE LINKAGE}

always ensures the supply of inputs such as materials, machinery, equipment, experts and even valuable information with a bigger aim to ensure smooth and timely production and distribution of products and services to customers.

This study focuses only on external links among the members of the supply chain, from input suppliers to processors and exporters in the fishery chain specifically.

\section{Factors affecting supply chain linkages}

Many scholars argue that supply chain linkage is always subject to global competitive pressure and/or to the risks related to environmental fluctuations, including changes in supply, demand, technologies (Chen \& Paulraj, 2004; Mentzer et al, 2001) or due to new market opportunities (Frohlich \& Westbrook, 2002).

According to some experts in the fisheries industry, the latter has a very high degree of dependence on the external environment, while this environment, in its turn, has high instability and often brings in many risks for the organizations involved in production and other core business processes. Some authors argue that this is a positive relationship, meaning that when the environment is getting unstable and risky — organizations tend to strengthen their links. Meanwhile, some other studies alternatively suggest that this relationship is of reverse nature: the higher are the risks - the less likely would be organizations to link together (Zhao et al., 2013).

\section{The relationship between risk and supply chain linkages}

Risks are defined in many different ways, depending on a particular field. In business management, for example, risk is defined as the uncertainty of possible future results. Risks may mean both positive and negative results. However, risks are mostly perceived in a negative way such as something not satisfying customer needs or affecting customer safety. Risks can also be classified into pure risks or speculative risks. Risks related to market demand are usually directly related to volatile, complex and unstable market demands. Businesses often face difficulties in meeting customer needs in such an environment. Christopher \& Lee (2004) and Punniyamoorthy et al. (2011) in relation to supply chain research specifically, outline the following groups of risks: supply risks, market risks, risks from information sources and environmental risks.

Supplier risk is usually related to the low capacity of planning and production, resulting in unstable production, unbalanced production systems and/or inadequate production processes, the inability to apply new technologies in production (Punniyamoorthy et al., 2011). Supply risks mean inadequate delivery, failing to meet the quantity and quality requirements, thus negatively affecting supply chain links (Zhao et al., 2013). In such a situation, customer confidence and cooperation with manufacturers will go down. In the case of the seafood supply chain in Ba Ria-Vung Tau province, there seems to be a negative relationship between the level of risk and cooperation among the members. Hence, our first hypothesis is put forward as follows:

H1: Supply risks have a negative relationship with the level of enterprise-supplier linkage (H1a) and the level of business-to-customer linkage (H1b). 
Risks from market demand usually happen due to fluctuating market demand or the complex and unstable nature of this demands. High-risk markets are characterized by constantly changing and difficult to forecast customer demand. When market risks are high, manufacturers must constantly change products, output etc. (Thomson, 2007).

This, in turn, affects the supply of raw materials from suppliers to manufacturing enterprises. Finally, fluctuating and changing market demand makes it difficult for producers to identify market demand through collection of customer feedback, as proper linking with customers becomes hard (Cavinato, 2004). Hence, the next hypothesis is put forward as follows:

$\mathrm{H} 2$ : Market risks have a negative relationship with the level of business linkages with suppliers (H2a) and the degree of linkage between businesses and customers (H2b).

Risks from information sources include information that is not available, information that is provided with delays, broken information infrastructure causing disruptions or when sources of information lack security (Punniyamoorthy et al., 2011). Information is an important factor for effective coordination between functional departments within a business as well as among the supply chain members (Lee \& Whang, 2000). Increasing cooperation and information sharing with members of a supply chain is seen as an effective solution to address this effect (Lee \& Whang, 2000). Risks caused by the lack of information include: delayed information provision, the use of information systems with security issues which are affecting the performance and linking between teams and also between members of the same team (Christopher \& Lee, 2004). Hence, our following hypothesis is put forward as:

H3: Risks from information sources have a negative relationship with the level of business linkages with suppliers (H3a) and the level of business linkage with customers (H3b).

In the field of supply chain management, environmental impact on organizations have been studied quite frequently. Duijn et al. (2012) asserted that organizations that form partnerships in supply chains thus get a way to limit the negative impacts from environmental instability. Mentzer et al. (2000) study supported this assumption, also adding that increased global competition increases the instability of the environment and encourages the linkages between the members of supply chains. Risks within a supply chain may occur due to the impacts from political, economic, social, natural environment, and these risks increase as the supply chain is expanding, becoming more complex (Khan \& Burnes, 2007). Our next hypothesis is thus formulated as follows:

H4: Risks from the environment have a negative relationship with the level of business linkages with suppliers (H4a) and the level of business linkage with customers (H4B).

\section{The relationship between supply chain linkages and business results}

There are many ways and criteria to measure the business results of organizations in the context of supply chain management. Business results can be measured under three levels: resource use, output and flexibility (Barney \& Tyler, 1991). The presence of resource use here implies a certain level of efficiency (which can be measures, for example, through the total cost of resources used and the revenues on investment capital). The measure of output here implies customer service or related consumption (revenues, profit and time spent 


\section{FACTORS AFFECTING THE LINKAGE}

on meeting customer needs in full. Finally, a certain degree of flexibility is needed here which is seen as the capacity to adapt to changes in the environment (for example, the rate of reducing the number of orders delayed by customers or the level of improvement in customer care \& satisfaction).

The most common division of measures in the field of supply chain management is dividing into operational results (productivity) and business results (competitive advantage, growth rate, financial results). This division is usually seen to be consistent with the actual business performance measurement (Flynn et al., 2010). Another fundamental goal is to improve customer service by increasing the availability of inventory and reducing the order cycle at the same time. Finally, low costs and excellent customer service will increase the competitive advantage for the entire supply chain (Cooper et al., 1997).

Thus, effective supply chain management will increase operational results (mainly through the reduction of costs) and business efficiency (including capital efficiency), at the same time increasing customer satisfaction with goods. Ultimately, all of the above means increasing profitability of the business overall.

Cooperation with key suppliers and important customers will reduce costs; improve product quality as well as service quality. Taken together, these improvements will help improve both productivity and business results. However, further verification of this relationship is necessary. Therefore, our two last hypotheses are formulated as follows:

H5: Linking with suppliers has a positive impact on the business results of businesses.

H6: Linking with customers has a positive impact on the business results of businesses.

\section{Models and research hypotheses}

Our research has covered the managers with some experience and knowledge in management of the activities within seafood supply chains of the Ba Ria-Vung Tau province. The next logical step would be to determine the appropriate sample size. There are many different ways to determine it. Sample size should be equal to the number of variables multiplied by 10 (Robson, 2002; Field, 2005). The number of variables in this study is 30, therefore, the sample size should be 30 x $10=300$. However, Nunnally, J. C. \& Bernstien, I. H. (1994) also suggested that the sample size needs to consider the rate of feedback from the investigated people. The response rate in our pilot survey was $78.14 \%$. Thus, the minimum sample size should be 384 ((300 x 100) / 78)), meaning that the minimum number of votes generated is 400 votes and at least 384 votes should be collected. To make sure we pass this requirement, the initial number of was 450 and the number of returned answers was 396.

Data analysis: This study uses exploratory factor analysis (EFA) and validation factor analysis (CFA) along with structural equation model (SEM) to test the hypotheses above. SEM is clear and testable so that competing models can be analyzed, synthesized and understood and their effects can be investigated directly, indirectly or both.

Reliability and validity. Internal consistency of the questionnaires was determined through the calculation of Cronbach alpha coefficients using step-by-step reliability analysis. Internal inconsistencies were deleted consecutively, thus maximizing the reliability of the scale at 0.70. Cronbach coefficient alphas are accepted (when exceeding 0.7). This implies that the measuring instruments are quite reliable. 
Table 1 - Definition of factors mentioned in the research hypotheses, authors' compilation (made by co-authors)

\begin{tabular}{|c|l|c|}
\hline Factors & \multicolumn{1}{|c|}{ Definition } & Hypotheses \\
\hline $\begin{array}{c}\text { Supply risks } \\
\text { (SR) }\end{array}$ & $\begin{array}{l}\text { Supply risks such as inadequate delivery or } \\
\text { failing to meet the quantity and quality } \\
\text { requirements may negatively affect the supply } \\
\text { chain links }\end{array}$ & H1a \\
\hline $\begin{array}{c}\text { Market risks } \\
\text { (MR) }\end{array}$ & $\begin{array}{l}\text { Risks from market demand happen due to } \\
\text { fluctuating market demand, complex or unstable } \\
\text { market demands }\end{array}$ & H2a \\
\hline $\begin{array}{c}\text { Information risk } \\
\text { (IR) }\end{array}$ & $\begin{array}{l}\text { Increasing cooperation and information sharing } \\
\text { with the members of a supply chain is seen as an } \\
\text { effective solution to address this effect }\end{array}$ & H3a \\
\hline $\begin{array}{c}\text { Environmental } \\
\text { risks (ER) }\end{array}$ & $\begin{array}{l}\text { Consumer behavior and consumer knowledge } \\
\text { are the main constructs here }\end{array}$ & H4a \\
\hline $\begin{array}{c}\text { Linking } \\
\text { businesses with } \\
\text { suppliers (LBS) }\end{array}$ & $\begin{array}{l}\text { Cooperation among members of a supply chain } \\
\text { will help businesses expand their market shares, } \\
\text { reduce costs and ensure sustainable development } \\
\text { overall }\end{array}$ & H5 \\
\hline $\begin{array}{c}\text { Linking } \\
\text { business with } \\
\text { customers } \\
\text { (LBC) }\end{array}$ & $\begin{array}{l}\text { Linking logistics activities with suppliers and } \\
\text { customers improves the results for both sellers } \\
\text { and buyers }\end{array}$ & $\begin{array}{l}\text { Business results can be measured in three } \\
\text { dimensions: resource use, output and flexibility }\end{array}$ \\
\hline $\begin{array}{c}\text { Business } \\
\text { results (BS) }\end{array}$ & Business results \\
\hline
\end{tabular}

\section{Discussion of the obtained results}

Our research model is based on the relevant models from the studies abroad. It is expected to measure the factors affecting the supply chain situation when applied to a specific case in Bà Rịa Vũng tàu province. However, its reliability should be retested.

\section{Cronbach alpha confidence factor}

Table 2 shows that the Cronbach's alpha coefficients of all the scales are greater than 0.7 , and the coefficients of variation are greater than 0.4 . This means that all these scales can be used further for EFA and regression analysis (Nunnally \& Burnstein, 1994). 
FACTORS AFFECTING THE LINKAGE

Table 2 - Test results for Cronbach's Alpha scales (authors' calculation)

\begin{tabular}{|c|l|c|c|c|}
\hline $\mathrm{N}_{0}$ & \multicolumn{1}{|c|}{ Scales } & $\begin{array}{c}\text { N of } \\
\text { Items }\end{array}$ & $\begin{array}{c}\text { Corrected Item } \\
\text { Total } \\
\text { Correlation }\end{array}$ & $\begin{array}{c}\text { Cronbach's } \\
\text { Alpha if Item } \\
\text { Deleted }\end{array}$ \\
\hline 1 & Supply risks (SR) & 5 & 0.769 & 0.569 \\
\hline 2 & Market risks (MR) & 5 & 0.869 & 0.718 \\
\hline 3 & Information risk (IR) & 5 & 0.819 & 0.551 \\
\hline 4 & Environmental risks (ER) & 5 & 0.843 & 0.625 \\
\hline 5 & Linking businesses with suppliers (LBS) & 5 & 0.813 & 0.567 \\
\hline 6 & Linking business with customers (LBC) & 5 & 0.880 & 0.727 \\
\hline
\end{tabular}

Confirmation factor analysis (CFA): The correlation coefficients between the components with the accompanying standard deviation (Tab. 2) show us that these coefficients are smaller than 1 (that is, statistically significant).

\section{Results of the Confirmatory Factor Analysis (CFA)}

The results of measuring the scale of business results with CFA show that Chi-square is 494.987 with 251 degrees of freedom $(\mathrm{P}=0.000)$, the relative degree of freedom of the mean square of Cmin / df $=1.972(<2)$. Other indicators are: GFI $=0.903(>0.9)$, TLI $=0.929$ $(>0.9), \mathrm{CFI}=0.941(>0.9)$ and RMSEA $=0.052(<0.08)$. Therefore, this model has achieved compatibility with the data collected (Fig. 2).

Table 3 - CFA results

(authors' calculation)

\begin{tabular}{|c|c|c|c|c|c|c|}
\hline \multicolumn{3}{|c|}{ Relations } & Estimate & S.E. & C.R. & P \\
\hline MR & $<-->$ & IR & 0.112 & 0.023 & 4.971 & $* * *$ \\
\hline MR & $<->$ & ER & 0.061 & 0.027 & 2.311 & 0.021 \\
\hline MR & $<->$ & BS & 0.105 & 0.032 & 3.274 & 0.001 \\
\hline MR & $<->$ & LBS & 0.224 & 0.029 & 7.761 & $* * *$ \\
\hline MR & $<-->$ & SR & 0.107 & 0.021 & 5.136 & $* * *$ \\
\hline MR & $<-->$ & LBC & 0.173 & 0.024 & 7.325 & $* * *$ \\
\hline IR & $<-->$ & BS & 0.084 & 0.027 & 3.077 & 0.002 \\
\hline IR & $<-->$ & LBS & 0.12 & 0.022 & 5.49 & $* * *$ \\
\hline IR & $<->$ & SR & 0.075 & 0.017 & 4.34 & $* * *$ \\
\hline IR & $<->$ & LBC & 0.131 & 0.02 & 6.635 & $* * *$ \\
\hline ER & $<->$ & BS & 0.18 & 0.037 & 4.928 & $* * *$ \\
\hline ER & $<-->$ & SR & 0.056 & 0.021 & 2.71 & 0.007 \\
\hline ER & $<-->$ & LBC & 0.04 & 0.022 & 1.862 & 0.063 \\
\hline
\end{tabular}




\begin{tabular}{|c|c|c|c|c|c|c|}
\hline BS & $<->$ & LBS & 0.078 & 0.029 & 2.715 & 0.007 \\
\hline BS & $<->$ & SR & 0.078 & 0.025 & 3.108 & 0.002 \\
\hline BS & $<->$ & LBC & 0.077 & 0.026 & 2.933 & 0.003 \\
\hline LBS & $<-->$ & SR & 0.152 & 0.023 & 6.647 & $* * *$ \\
\hline LBS & $<-->$ & LBC & 0.131 & 0.021 & 6.251 & $* * *$ \\
\hline SR & $<->>$ & LBC & 0.091 & 0.018 & 5.19 & $* * *$ \\
\hline
\end{tabular}

\section{Structural equation modeling (SEM) results}

SEM has been developed to explore the relationship between supply risk (SR), market risk (MR), information risk (IR), environmental risk (ER), business linkage with suppliers (LBS), business associations with customers (LBC) and business results (BS).

The results show that the final calibration model with statistically significant Chisquare is 421.216 with 211 degrees of freedom $(\mathrm{P}=0.000)$, the relative degree of freedom of the mean square of $\mathrm{Cmin} / \mathrm{df}=1.996(<2)$. Other indicators are: GFI $=0.910(>0.9)$, TLI $=$ $0.931(>0.9), \mathrm{CFI}=0.943(>0.9)$ and RMSEA $=0.053(<0.08)$. Therefore, this model has achieved compatibility with the data collected (Figure 3 ).

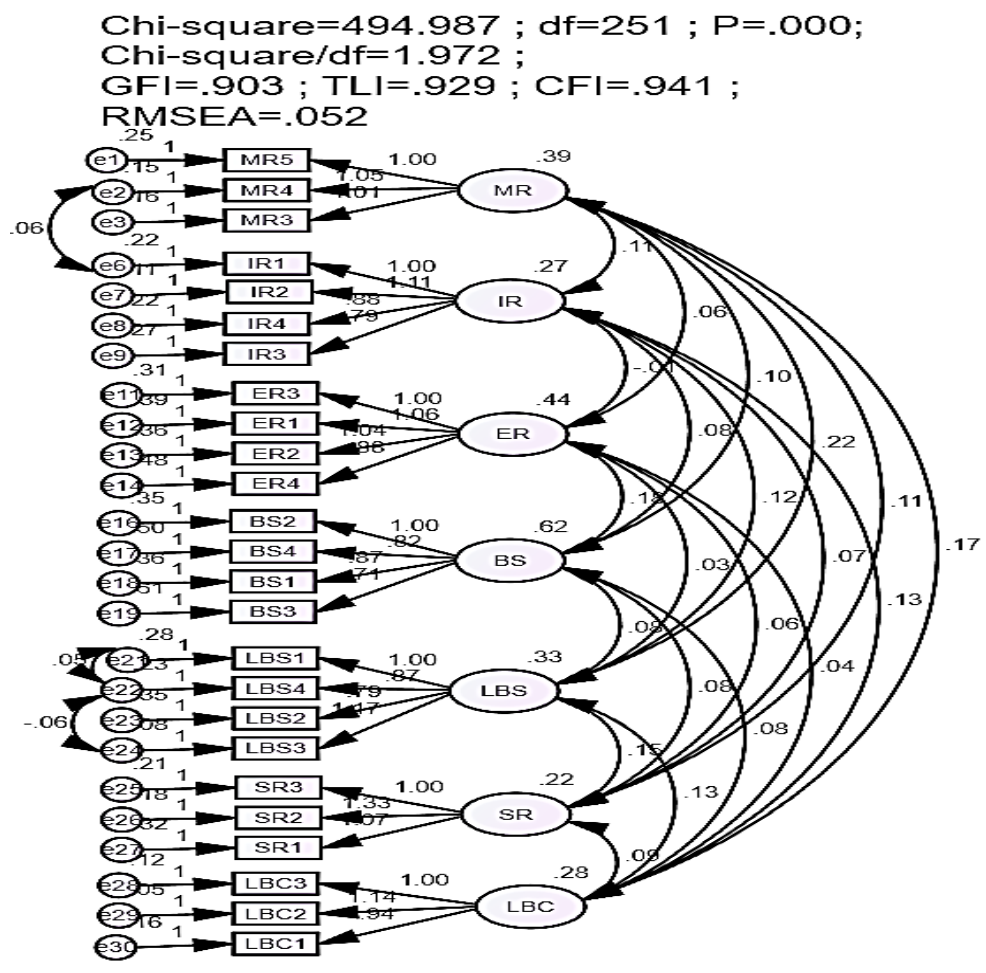

Figure 2 - Results of the relational CFA (made by the authors') 


\section{FACTORS AFFECTING THE LINKAGE}

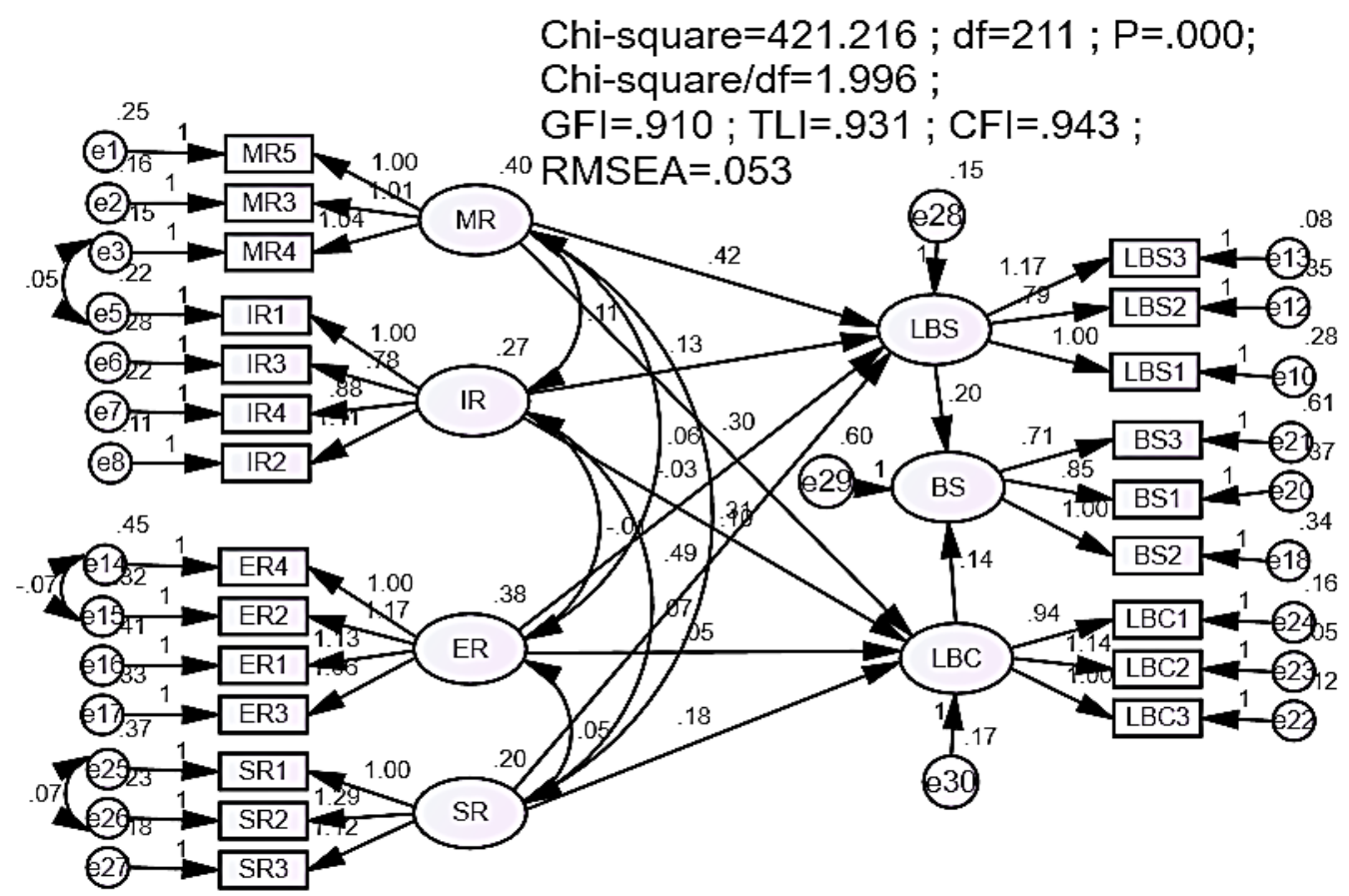

Figure 3 - The relationship between risk, supply chain linkage and business results (made by the authors')

Table 4 - Results of estimating the relationships between risk, supply chain linkage and business results (made by the authors')

\begin{tabular}{|c|c|c|c|c|c|c|c|}
\hline \multicolumn{2}{|c|}{ Regression Weights } & Estimate & S.E. & C.R. & P & Label \\
\hline LBC & $<---$ & MR & 0.299 & 0.050 & 6.013 & $* * *$ & Yes \\
\hline LBC & $<---$ & IR & 0.311 & 0.059 & 5.288 & $* * *$ & Yes \\
\hline LBC & $<---$ & ER & 0.046 & 0.044 & 1.034 & 0.028 & Yes \\
\hline LBC & $<---$ & SR & 0.177 & 0.074 & 2.377 & 0.059 & No \\
\hline LBS & $<---$ & SR & 0.488 & 0.094 & 5.197 & $* * *$ & Yes \\
\hline LBS & $<---$ & ER & -0.033 & 0.046 & -0.728 & 0.011 & Yes \\
\hline LBS & $<---$ & IR & 0.135 & 0.059 & 2.299 & 0.015 & Yes \\
\hline LBS & $<---$ & MR & 0.416 & 0.056 & 7.360 & $* * *$ & Yes \\
\hline BS & $<---$ & LBS & 0.202 & 0.100 & 2.027 & 0.040 & Yes \\
\hline BS & $<---$ & LBC & 0.144 & 0.107 & 1.356 & 0.035 & Yes \\
\hline
\end{tabular}

\section{Testing the reliability of estimates by means of bootstrap}

The bootstrap method is applied here to test the final model estimation with the repeat pattern of $\mathrm{N}=1000$. The estimated results from 1000 averaged samples along with the deviations are shown in Table 4. CR has the absolute value which is less than 2. It can be said that deviation is very small here while not statistically significant at the $95 \%$ confidence level. Therefore, we can conclude that model estimates can be trusted. 
Table 5 - Bootstrap results, $\mathrm{N}=1000$

(Authors' own calculations in SPSS 23.0)

\begin{tabular}{|c|c|c|c|c|c|c|c|c|c|}
\hline \multicolumn{3}{|c|}{ Parameters } & Estimates & SE & SE-SE & Mean & Bias & SE-Bias & $\mathrm{CR}$ \\
\hline LBC & $<--$ & MR & 0.298 & 0.061 & 0.001 & 0.297 & -0.001 & 0.002 & -0.5 \\
\hline LBC & $<---$ & IR & 0.314 & 0.077 & 0.002 & 0.316 & 0.002 & 0.002 & 1 \\
\hline LBC & $<--$ & ER & 0.048 & 0.055 & 0.001 & 0.047 & -0.001 & 0.002 & -0.5 \\
\hline LBC & $<---$ & SR & 0.177 & 0.099 & 0.002 & 0.182 & 0.005 & 0.003 & 1.67 \\
\hline LBS & $<---$ & SR & 0.554 & 0.15 & 0.003 & 0.551 & -0.003 & 0.005 & -0.6 \\
\hline LBS & $<---$ & ER & 0.038 & 0.043 & 0.001 & -0.034 & 0.004 & 0.001 & 4 \\
\hline LBS & $<---$ & IR & 0.137 & 0.07 & 0.002 & 0.137 & -0.001 & 0.002 & -0.5 \\
\hline LBS & $<--$ & MR & 0.391 & 0.082 & 0.002 & 0.394 & 0.003 & 0.003 & 1 \\
\hline $\mathrm{BS}$ & $<--$ & LBS & 0.16 & 0.107 & 0.002 & 0.163 & 0.003 & 0.003 & 1 \\
\hline BS & $<---$ & LBC & 0.218 & 0.111 & 0.002 & 0.211 & -0.007 & 0.004 & -1.75 \\
\hline
\end{tabular}

\section{Conclusions and recommendations}

\section{For reducing market risks}

Increasing price competitiveness

Some of the enterprises in question have a sufficient potential to enter large markets (Middle East, China) but they do not meet their high-quality requirements. Thus, these enterprises continue to implement low price \& moderate quality strategies. For high-end markets (Japan, EU, USA), businesses are gradually shifting to high prices and high quality. Enterprises need to be familiar with the anti-dumping laws in all key importing countries, their regulations under free trade agreements and demonstrate the commitment to comply with such laws.

Stable and gradually expanding the market, while diversifying export products

Exporting seafood organizations need to maintain stability and diversify export markets through various measures such as investment in trade promotion through various forms (market research, advertising, release information through catalogs and websites etc.); to exploit more e-commerce applications to promote business and its introduction capacities; to find potential customers; to collect customer information, receiving customer feedback; to organize export market surveys and so on.

Supporting businesses in registering and promoting product brands with geographical indications for key processed seafood products

The Department of Science and Technology needs to support businesses that are registering collective brands and geographical indications for key processed seafood products. Branding should be based on product quality and service quality associated with product consumption and corporate reputation.

\section{Reducing information risks}

If information is accurate, its management and use will bring in accurate results. Enterprises need to exploit information from a variety of sources in the most proactive way and must integrate them into the supply chain. In particular, the database must be synchronizing the purchase of raw materials, production, storage and distribution. Thereby, 


\section{FACTORS AFFECTING THE LINKAGE}

enterprises can forecast and plan the supply chain timely and accurately, thus minimizing risks.

\section{Reducing environmental risks}

Building a model of production facilities to improve the water environment in accordance with GMP / ISO quality control system

(1) Analyzing quality criteria, banned substances, antibiotics used in aquaculture according to the regulations of the Ministry of Agriculture and Rural Development;

(2) Monitoring the quality of food products, water treatment, and aquaculture treatment;

(3) Developing programs for technical guidance to reduce pollution and measures to treat environmental pollution. Building and certifying quality control systems according to GMP or ISO;

(4) Organizing and carrying out training to raise awareness about water sources protection and treating pollution emissions outside production facilities;

(5) Planting fruit trees on the shores since they can minimize erosion during the rainy season and also provide shade and shelter for aquatic species during high water temperatures.

Developing business strategies to strengthen supply chain linkages

Support should be provided for the development of vertical links, especially between leading enterprises and aquaculturists, to ensure stable input and high-quality output. The connection between seafood businesses and local farmers is the key issue, as it ensuring the interests of both parties. Enterprises purchase local products under the prices that ensure farmers have profit sufficient for further ongoing production. As a result, enterprises will be assured of both raw materials for processing and export.

\section{Contributions and limitations of this research}

This study has verified and explained the impact of supply chain linkages on the business results of its members. Although there are many studies on this relationship, it is still necessary to test this complex relationship and clarify the nature of this notion and the reasoning on this issue (Fabbe-Costes \& Jahre, 2008). Evidence from the same industry but in a developed country can provide meaningful data for further comparison since most previous studies have been primarily conducted in developed countries.

Our study is also verifying the relationship between risk, supply chain linkages and business results, thus confirming the correctness of the theory of the relationship between environment and organizational structure (Aldrich \& Pfefer, 1976). This also affirms that the environment has its impact on organizations and that organizations need to change to suit the environmental changes.

Clarifying the relationship between strategy, supply chain linkages and business results can help determining the correctness of the theory of strategic relationships, organizational structure and business results in a supply chain.

This study also helps managers understand the important role of identifying and having solutions that limit the impact of risks on supply chain connectivity. There must be a method of determining the types of risks that occur on the side suppliers, markets, related information, and the environment overall. Next comes measuring the level of risk occurrence 
and its impact on the supply chain linkage. The final stage would be looking for solutions to limit the impact of these risks.

\section{Some limitations of this research}

The first drawback of this study is that data collection took place only once, while the influence of supply chain linkages on normal business results takes place over a certain period of time. Therefore, follow-up studies should test this relationship over a period of time so that to get more accurate results.

The second limitation of the study is that enterprises' performance has been measured using qualitative indicators only. In addition, the scales depended greatly on the perception of the person who filled in the questionnaire. Therefore, future research should use quantitative and objective data to get better results.

\section{References:}

Aldrich, H. E. \& Pfeffer, J. (1976). Environments of organizations. Annual Review of Sociology, 2, 79-105.

Anderson, E. \& Weitz, B. (1992). The use of pledges to build and sustain commitment in distribution channels. Journal of Marketing Research, 1 (29), 18-34.

Barney, J. B., \& Tyler, B. (1991). The prescriptive limits and potential for applying strategic management theory. Managerial and Decision Economics, 17 (1), 99-120.

Cavinato, J. L. (2004). Supply chain logistics risks: From the back room to boardroom. International Journal of Physical distribution \& Logistics Management, 34 (5), 383-387.

Chen, I.J. \& Paulraj, A. (2004). Towards a theory of supply chain management: the constructs and measurement. Journal of Operations Managements, 22, 119-150.

Christopher, M. \& Lee, H. L. (2004). Mitigating Supply Chain Risk through Improved Confidence. International Journal of Physical Distribution and Logistics Management, 34 (5): 388-396.

Cooper, M.C., Lambert, D.M. \& Pagh, J.D. (1997). Supply chain management: more than a new name for logistics. International Journal of Logistics Management, 1 (8): 1-14.

Duijn, A. P. V., Beukers, R., \& Pijl, W. V. D. (2012). The Vietnamese seafood sector: A value chain analysis. CBI (Center for the promotion of imports from developing countries), Netherlands.

Fabbe-Costes, N., \& Jahre, M. (2008). Supply chain integration and performance: a review of the evidence. The International Journal of Logistics Management, 19 (2), 130-154.

Flynn, B.B., Huo, B. \& Zhao, X. (2010). The impact of supply chain integration on performance: a contingency and configuration approach. Journal of Operations Management, 28 (1), 5871.

Frohlich, M.T. \& Westbrook, R. (2001). Arcs of integration: An international study of supply chain strategies. Journal of Operations Management, 19 (2), 185-200.

Khan, O. \& Burnes, B. (2007). Risk and supply chain management: creating a research agenda. The International Journal of Logistics Management, 18 (2), 197-216.

Lambert, D., \& Cooper, M. (2000). Issues in the supply chain management. Journal of Industrial Marketing Management, 29, 65-83.

Lee, H. L., \& Whang, S. (2000). Information sharing in a supply chain. International Journal of Technology Management, 20 (3), 373-387.

Mentzer, J.T., DeWitt, W., Keebler, J.S., Min, S., Nix, N.W. \& Zacharia, Z.G. (2001). Defining supply chain management. Journal of Business Logistics, 22 (2), 1-25.

Nunnally, J. C. \& Bernstien, I. H. (1994). Psychometric theory, 3rd ed., New York: McGraw Hill. 


\section{FACTORS AFFECTING THE LINKAGE}

Punniyamoorthy, M., Thamraiselvan, N. \& Manikandan, L. (2011). Assessment of supply chain risk: scale development and validation. Benchmarking. An International Journal, 20 (1), 79-105.

Thomson, L. (2007). Accessing global value chain? The role of business-state relations in the private clothing industry in Vietnam. Journal of Economic Geography, 6 (7), 753-776.

Zhao, L., Sun, L., \& Zhao, X. (2013). The impact of supply chain risk on supply chain integration and company performance: a global investigation. Supply chain management: An International Journal, 182, 115-131.

Paper submitted

Paper accepted for publishing

Paper published online
02 December 2019

25 January 2020

02 April 2020 